\title{
Új globális kezdeményezés -gyermekegészségügyi információt mindenkinek!
}

\author{
A new global initiative -Child Health Information For All
}

Ismertető: $\quad$ Kovács Zsuzsanna $\square$

Nyugalmazott házi gyermekorvos, Magyarország képviselöje a CHIFA-ban

Beküldve: $\quad$ 2019. 01. 12.

doi: $\quad$ 10.24365/ef.v60i1.400

Kulcsszavak: egészségügyi információ; internetes kapcsolat; önkéntes szakmai együttműködés

Keywords: health information; connection via internet; voluntary professional cooperation

A háziorvosi ellátásról szóló Alma Ata-i Deklaráció ${ }^{1}$ kimondja: „Az egészségügyi alapellátás céljai között szerepel a közösség fő egészségproblémáinak megoldása azáltal, hogy megfelelő egészségfejlesztési, betegségmegelőzési, gyógyító és rehabilitációs szolgáltatásokat nyújt."

E cél eléréséhez alapvető, hogy az egészséggel kapcsolatos korszerű információk érthető nyelven és optimális formában (elektronikus, nyomtatott, vetített vagy előadás) elérhetők legyenek.

Az elmúlt évtizedekben igen nagy fejlődés tanúi lehettünk a gyermekhalandóság csökkenése tekintetében. Ennek ellenére a WHO adatai szerint a 2017-ban meghalt 5,4 millió 5 éven aluli gyermek legalább fele megmenthető lett volna, ha elérhető lett volna a számukra a legegyszerübb egészségügyi ellátás. ${ }^{2}$

Egy 2009-ben megjelent irodalmi áttekintés a fejlődő országokban tevékenykedő egészségügyi dolgozók szükségleteit, ismereteit és gyakorlatát elemezte. ${ }^{3}$ Kimutatták, hogy a Föld népességének jelentős része nem jut hozzá a minimálisan megfelelő egészségügyi ellátáshoz sem, mivel az őket ellátó egészségügyi személyzet alapvető ismeretei még a banális betegségekkel kapcsolatosan is hiányosak. Ezért alapvető, hogy megfelelő egészségügyi információk eljussanak ezekbe a régiókba is, így világszerte javítani lehetne az egészségügyi ellátást.

Sok ezer egészségügyi informátor múködik világszerte a WHO szakértőktől kezdve az önkéntes segítőkig. Meg kell említeni a Teaching Aids at Low Cost (TALC) csoport úttörő munkáját, melyet 1965-ben Prof. David Morley alapított. A TALC az internet előtti korban fantasztikus eredményeket ért el azzal, hogy a fejlődő világban sok millió könyvet és egyéb tájékoztató anyagot terjesztett el az egészségügyben dolgozók körében. ${ }^{4}$

$\mathrm{Az}$ internet és a mobiltelefon-hálózat egyre nagyobb elterjedése új lehetőséget teremtett az információk terjesztésére. A WHO 2004-ben publikált elemzése szerint a Milleneumi Fejlesztési Célok eléréséhez még mindig nagyon sok a tennivaló. ${ }^{5}$ A tanulmány külön kitér az egészségügyi ellátás egyenlőtlenségére és az információk hiányára. ${ }^{6}$ Erre reagálva Godlee és munkatársai javaslatot tettek a WHO felé, hogy játsszon vezető szerepet a megfelelő egészségügyi információk mindenki számára elérhetővé tételében.

E cél elérésének egyik fontos állomása, hogy 2006 októberében Kenyában az Association for Health Information and Libraries in Africa 10. kongresszusán elindult egy internetes hálózat, a HIFA (Healthcare Information For All), ${ }^{7}$ és ennek 
keretein belül a CHIFA (Child Health and Rights). Mindkét hálózat az internet útján kapcsolatot teremt különböző szakterületeket képviselő szakemberek között, akik kisebb térségekben vagy globális szinten a hátrányos helyzetű gyermeklakosságra és családjaikra, illetve a fejlődő országokra fókuszálva érdekeltek az egészségmegőrzésben. E szakemberek - orvosok, nővérek, kisegítő személyzet, akadémikusok, könyvtárosok, szakújságírók, könyvkiadók, politikusok, kutatók - tapasztalatokat, információkat cserélnek, és így hozzájárulnak az egészségügyi ellátás javításához. A nemzetközi levelezőfórum tagjai aktuális régiós, kontinentális vagy globális egészségügyi kérdéseket vetnek fel és tárgyalnak meg. Felhívják a figyelmet neves szaklapokban (pl. Lancet) publikált kutatásokra, illetve jó gyakorlatokat, módszertani iránymutatásokat tesznek közzé, melyek segítséget jelenthetnek vagy hivatkozási lehetőséget nyújtanak más országok szakemberei számára (akár az ország társadalmi - gazdasági fejlettségétől függetlenül is).
A HIFA és a CHIFA hálózatnak együtt ma már 178 országból több mint 18500 tagja van az ún. fejlődő és a fejlett világból egyaránt. A fórum múködését 325 szakmai szervezet támogatja, ezen belül 38 anyagilag is segíti. A hat interaktív fórum négy nyelven múködik (angol, francia, portugál és spanyol).

A CHIFA víziója egy olyan világ, ahol minden gyermek, minden szülő és minden egészségügyi dolgozó meg tudja szerezni a rendelkezésre álló és alapvető tudást, mellyel mind a saját, mind a rábízott gyermekek egészségét meg tudja őrizni, vagy időben és hatékonyan be tud avatkozni. Emellett a gyermekjogok érvényesítését is feladatának tekinti.

A CHIFA hálózatnak több mint 140 országból több mint 3500 tagja van.

\section{1. ábra: a CHIFA tagjais}

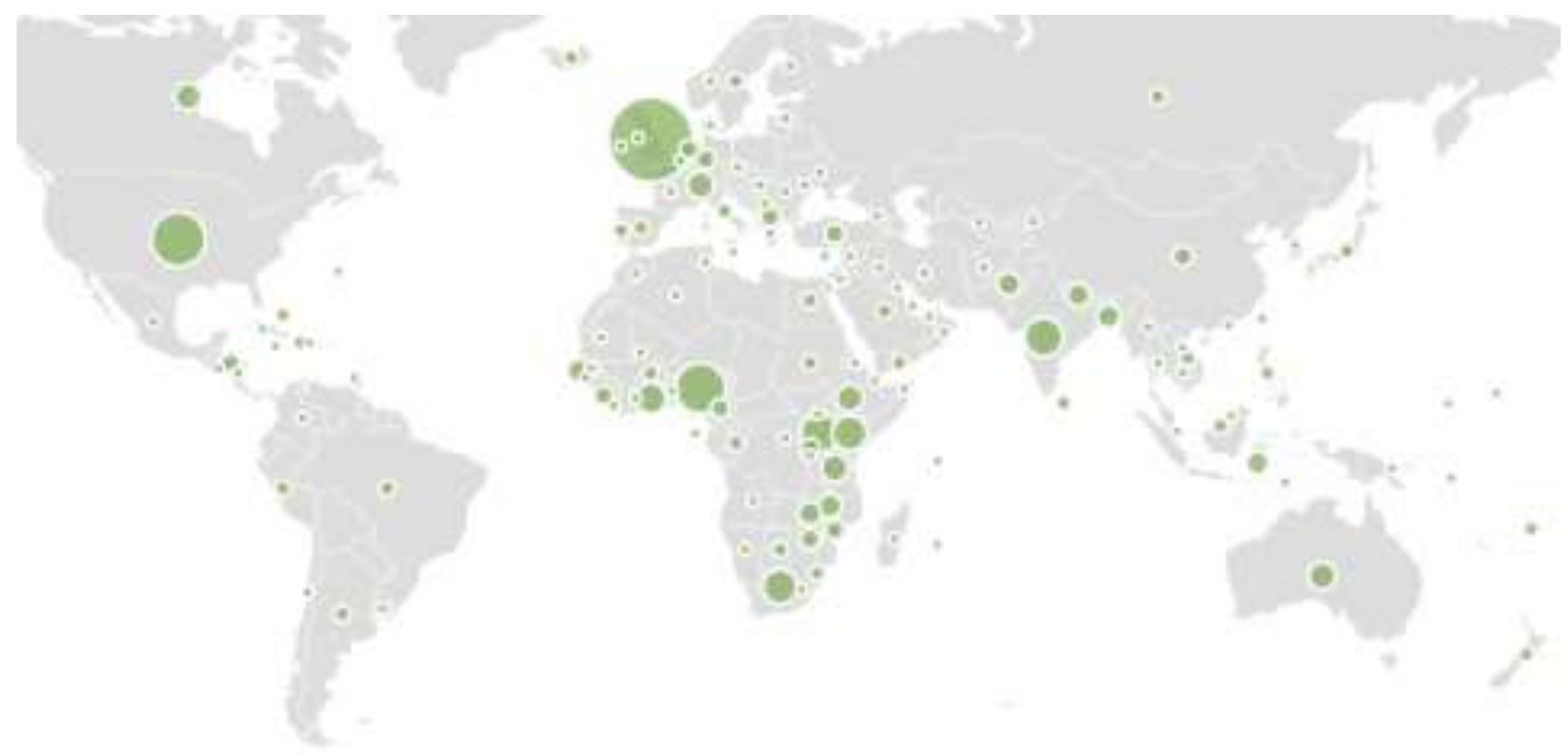

Forrás: http://www.hifa.org/forums/chifa-child-health-and-rights 
A CHIFA üzemeltetését az International Child Health Group of the Royal College of Paediatrics and Child Health, valamint az ISSOP (International Society for Social Pediatrics and Child Health) szakmai társaságok egymással együttmúködve biztosítják.

A CHIFA internetes levelezési fórumain széleskörű szakmai egyeztetések zajlanak különböző szakemberek - alapellátók, akadémikusok, WHO és egyéb szervezetekben tevékenykedő szakemberek, politikusok, gyógyszerészek, újságírók, kiadók és médiaszakértők között, ritkábban szülők és gondozók is bekapcsolódnak. Néhány példa a megvitatott kérdések közül:

- szoptatás és a tápszergyártók szerepe

- gyermek joga az egészségügyi ellátáshoz

- népi gyógyászat

- földimogyoróvaj használata akut sorvadás esetén

- indokolatlan antibiotikum-használat

- újszülött ellátása

- videojátékok hatása a pszichés és testi fejlődésre

- nemi szervek megcsonkítása

- gyermekbántalmazás

Az elektronikus levelezés itt megtekinthető: http://www.hifa.org/rss-feeds/10

A legújabb témát, az újszülöttek ellátásának javítását, különös tekintettel a koraszülött és kis súlyú újszülöttek ellátására, a London School of Hygiene and Tropical Medicine munkacsoportjával együttmúködésben tárgyalták meg.

A CHIFA ezen kívül webkonferenciákat is szervezett az alábbi témákban:

- gyermekbántalmazás

- testi fenyítés a családban

- védőoltás és gyermekjogok

A CHIFA szerény anyagi háttérrel és sok önkéntessel múködve jelentős eredményeket ért el.
A további eredmények eléréséhez szükséges feladatok:
- országok képviselőinek aktivitását erősíteni
- támogató szervezetek szerepét kiterjeszteni
- speciális projekteket fejleszteni, Id. újszülött projekt
- együttműködés és fórumhasználat előnyeit értékelni
- rendszeres webkonferenciákat szervezni
- WHO-val és egyéb intézményekkel szorosabb együttmúködést kialakítani

A HIFA/CHIFA-közösség nyitott, a levelezőfórumhoz csatlakozás ingyenes.

Ezúton tisztelettel meghívjuk csatlakozásra a világra nyitott, érdeklődő magyar szakembereket is.

Regisztráció:

HIFA: http://www.hifa.org/join/join-hifa-english

CHIFA: http://www.hifa.org/join/join-chifa-childhealth-and-rights

\footnotetext{
${ }^{1}$ Alma-Ata-i Nyilatkozat http://regi.oefi.hu/alapelvek.pdf

${ }^{2}$ WHO Children:reducing mortality https://www.who.int/news-room/fact-sheets/detail/childrenreducing-mortality

${ }^{3}$ Pakenham-Walsh N, Bukachi F. Information needs of health care workers in developing countries: a literature review with a focus on Africa. Hum Resour Health 2009;7:30. https://www.ncbi.nlm.nih.gov/pmc/articles/PMC2680393/pdf/1478-4491-7-30.pdf

${ }^{4}$ https://healthbooksinternational.org/

${ }^{5}$ Godlee F, Pakenham-Walsh N, Ncayiyana D, et al. Can we achieve health information for all by 2015 ? Lancet 2004;364:295-300 https://www.thelancet.com/pb-assets/Lancet/extras/04art6112web.pdf ${ }^{6}$ https://www.who.int/rpc/meetings/en/world report on knowledge for better health2.pdf

7 http://www.hifa.org/

${ }^{8}$ http://www.hifa.org/forums/chifa-child-health-and-rights
} 